Harold Horell, Fordham University GSRRE

horell@,fordham.edu

2013 REA Annual Meeting, Nov. 8-10, 2013

\title{
On Learning to See the World Religiously: Moral Awareness, Faith, and Public Moral Discourse
}

\begin{abstract}
Our moral awareness directs our attention to salient ethical cues in our lives. This paper discusses how an understanding of the dynamics of moral awareness can enable people to ground their moral outlooks in their faith commitments while at the same time remaining open to dialogue with people of other religious outlooks so that they are able to discuss moral issues in the religiously diverse social and public places (the public squares) of our global, postmodern age.
\end{abstract}

Imagine seeing a child being pushed roughly to the ground by another child on a playground. Imagine reading August 2013 reports about hundreds of Syrian civilians being killed by chemical weapons. Moral awareness is the tug of morality. It emerges when our attention is drawn to situations that raise questions about the wellbeing of persons or communities. In such situations moral issues come to the forefront of consciousness - prompting us to try to understand what is going on and leading us to consider how we, others, or communities can and should respond. ${ }^{1}$

How should our faith convictions inform our moral awareness? Morality is a constitutive dimension of faith. From a Christian perspective, we are called to show hospitality to the stranger, to have a special concern for the poor and the oppressed, and to respect the dignity of all persons as created in the image of God. ${ }^{2}$ More broadly, the great religious traditions of the world offer resources for forming and informing an understanding of the moral dimensions of life. For instance, a Christian vision of welcoming and working to bring about the fuller realization of the Reign of God, ${ }^{3}$ a Jewish understanding of tikkun olann (repair of the world) as

\footnotetext{
${ }^{1}$ The analysis of moral awareness presented in this paper draws insight from the work of James Rest. See James R. Rest, "Morality," in Manual of Child Psychology vol. 3, vol. ed. J. Flavell and E. Markman, gen. ed. P. Mussen (New York: Wiley, 1983), 558-561; James R. Rest et al., Moral Development: Advances in Research and Theory (New York: Praeger, 1986), 3-8; and Darcia Narvaez and James Rest, "The Four Components of Acting Morally," in Moral Development: An Introduction, ed. William M. Kurtines and Jacob L. Gewirtz (Allyn and Bacon, 1995), 385-392.

${ }^{2}$ See Thomas W. Ogletree, Hospitality to the Stranger: Dimensions of Moral Understanding (Philadelphia: Fortress, 1985); Ana Maria Pineda, "Hospitality," in Practicing our Faith, ed. Dorothy C. Bass (San Francisco: Josey Bass, 1997), 29-42; Gustavo Gutierrez, The Power of the Poor in History (Maryknoll; Orbis, 1983); Judith Ann Brady, A Place at the Table: Justice for the Poor in a Land of Plenty (New London, CT: Twenty-Third, 2008); on the dignity of the human person and respect for persons as persons see Dolores L. Christie, Moral Choice: A Christian View of Ethics (Minneapolis: Fortress, 2013), 105-131; on respect for persons as persons as central to religious education see Padraic O'Hare, "The Renewal of Education and the Nurturing of Justice and Peace," in Education for Peace and Justice, ed. by Padraic O'Hare (San Francisco: Harper and Row, 1983), 110-123.

${ }^{3}$ See Norman Perrin, Jesus and the Language of the Kingdom: Symbol and Metaphor in New Testament Interpretation (Philadelphia: Fortress, 1976), Lisa Sowle Cahill, Love Your Enemies: Discipleship, Pacifism, and Just War Theory (Minneapolis: Fortress, 1994), 15-38; and Thomas H. Groome, Christian Religious Education (San Francisco: Josey-Bass, 1980), 35-55.
} 
the spiritual purpose of life, ${ }^{4}$ and the Confucian concept of the cultivation of ren (humanity) as the ultimate goal of life, ${ }^{5}$ can all provide a foundation for robust moral visions. Hence, it can be argued that faith should shape moral awareness, and that religious education should form people to see moral issues in the light of their faith convictions.

However, questions are sometimes raised about the role of faith in contemporary public life. For instance, we might ask: When insights grounded within the situated convictions of specific religious traditions and communities are brought into public forums of discourse, aren't they more likely than not to cause tension and conflict given the religious diversity found throughout the world?

The next two sections focus on a few stories that can help us to understand more fully how faith becomes problematic in public forums of moral discourse. To address this problematic issue, the dynamics of moral awareness are then explored and guidelines are proposed for helping people learn how they can fruitfully draw insight from their faith convictions in discussing socio-moral issues. The paper focuses specifically on Christian moral awareness, but suggests ways people of diverse faith commitments can work together in addressing socio-moral issues in public forums of discourse.

Religious Insight and Public Moral Discourse: Blinded by the Light

Gerald (not his real name) began his freshman year in college by participating in a university-run, service program called Urban Plunge. He and other incoming freshman worked on various community projects in the neighborhood surrounding their urban college campus. Although the Jesuit, Catholic identity of the university was acknowledged in the program orientation, participants were told before each of their regular reflection sessions that it could cause conflict in their religiously diverse group if their personal reflections emphasized how their moral outlooks were grounded within their specific religious traditions. Instead, they were encouraged to focus on how their service deepened their commitment to the common good of society.

Urban Plunge expanded Gerald's moral outlook by bringing him into contact for the first time in his life with a diverse range of moral and religious perspectives. However, after his Urban Plunge experience and echoing the perspective of the Urban Plunge leaders, Gerald began

\footnotetext{
${ }^{4}$ See Elliot N. Dorff, The Way into Tikkun Olam (Repairing the World) (Woodstock, VT: Jewish Lights Publishing, 2005); and Sherry H. Blumberg, "Repairing the World: The Place of Mitzvot in Children's Spiritual Lives," in Nurturing Child and Adolescent Spirituality: Perspective from the World's Religious Traditions, ed. Karen Marie Yust et al. (Lanham, MD: Rowan and Littlefield, 2006), 275-284. I developed a fuller understanding of the moral and religious educational significance of the concept of tikkun olam through conversations with Cynthia Nienhaus, who is at Marian University, Fond du Lac, WI. For broader perspective on Jewish morality and moral education see Elliot N. Dorff and Louis E. Newman, eds. Contemporary Jewish Ethics and Morality (New York: Oxford, 1995) and the analysis of "Jewish Theologians and Moral Education" in John Elias, Moral Education: Secular and Religious (Malabar, FL: Robert E. Krieger, 1999), 149-156. Elias, as well as many of the essays in the book edited by Dorff and Newman, emphasize how a Jewish moral vision is both rooted in the particularly of Jewish faith and universal in scope.

${ }^{5}$ See Confucius, Confucius Analects, trans. by Edward Slingerland (Indianapolis, IN: Hacket, 2003), Book 12, verses1-2; and Book 6, verse 30; Joel J. Kupperman, "Ren and Li in the Analects," in Confucius on the Analects, ed. Bryan W. Van Norder (Oxford: Oxford University Press, 2002); and Francisca Cho, "Ritual," in The Blackwell Companion to Religious Ethics, ed. William Schweiker (Malden, MA: Blackwell, 2005), 88-90. My understanding of importance of ren as an ethical concept has been greatly enhanced by conversations with Imelda Lam, a religious educator who works for the Catholic Diocese of Hong Kong.
} 
to claim that too great a focus on the moral wisdom of any religious community could be blinding. That is, it could keep him from recognizing and being open to the moral insights of people of other religions. Then, throughout his years in college, Gerald questioned whether public moral discourse among people of diverse religious and philosophical convictions is possible. He also at times adopted a skeptical attitude and claimed that it is best to limit public discussions of morality to practical issues, focusing on coordinating action for the common good.

A few years later a student, Nikki (not her real name) asked me to discuss with her a proposal to create a program to help Catholics nurture a fuller sense of Catholic identity at the Catholic university where she worked. The proposal had been rejected on the grounds that it could be divisive. The Campus Ministry staff pointed out to Nikki that the staff included both Catholic and Protestant chaplains, offering both Catholic and Protestant services. However, staff members added that they were committed to the spiritual development of the school's religiously diverse student body, and that to hold up the moral vision of any religious tradition (even the founding tradition of the school) in the programs offered would be to fail to respect the many religions of students. Instead, their campus ministry programs emphasized the commonly shared human quest for the sacred or God.

Nikki disagreed. She argued that "a Catholic institution would be doing its students a great disservice if it provided a welcoming environment by sacrificing its Catholic identity." She added that in their commitment to open dialogue, including openness in discussions of moral issues, Campus Ministry staff members at her university have turned a blind eye to the wisdom of Catholicism and that, as a result, their spiritual and moral outlook has been impoverished. Nikki then claimed that in addressing moral issues, Catholics should begin with the moral wisdom found in Catholicism, striving to articulate an alternative moral vision to the dominant culture. Catholics, Nikki contended, should even be willing to assert the "superiority" of their moral perspective and show how the moral insights of others can be seen in a fuller light when viewed from a Catholic perspective.

In the above stories there is a sharp contrast between the Urban Plunge and campus ministry staffs, on the one hand, and Nikki, on the other. The members of the two program staffs focus on our common humanity. They contend that a focus on particular personal and religious commitments could blind us to basic or foundational moral inclinations (such as the tendencies to preserve life and seek community) that all people share and upon which personal and social life is built. In contrast, Nikki's focus is on what is distinctively Christian and particularly Catholic. She argues that Catholics compromise their Christian faith if they do not center their moral and religious outlooks in the unique revelation of God in Christ. From her perspective, a focus on our common humanity can blind us to the potentially world transforming moral vision presented in the life and ministry of Jesus and then carried forward in the church.

The third perspective presented in the above stories is that of Gerald. When discussing his Urban Plunge experience Gerald talked about becoming aware of the ways the moral perspectives he encountered were grounded in particular life stories and social contexts. For instance, Gerald commented on the strong sense of morality that was nurtured by the regular communal gatherings that took place in one neighborhood, and how this sense of community was deeply intertwined with the Catholicism of the people and their specific sense of ethnic identity. At the same time, Gerald accepted the claim of the Urban Plunge leaders that people need to step back from their rootedness in specific life contexts if they want to forge a shared sense of morality. In the end, Gerald felt caught between two conflicting insights. He recognized the inescapable situatedness of all moral perspectives, on the one hand, and he accepted the idea 
that we need to try to transcend our specific life context if we are to see moral issues objectively, on the other. This conflict sparked in Gerald a deeper level of critical reflection. However, it also led him to become skeptical at times about whether or not we can create public forums for people from diverse backgrounds to discuss moral issues in a fruitful way.

The three points of view presented here illustrate some of the major problems that arise today in striving to create public forums for the discussion of socio-moral issues among people of diverse religious and social backgrounds. These problems are discussed more fully in the next section.

\section{Public Moral Discourse as Problematic}

In the past it was sometimes possible to stress the importance of shared moral convictions and a sense of common humanity in striving to create public forums for moral discourse. For example, in the Catholic neighborhood in which I grew up, almost everyone attended the same church, was educated in one of two local schools, and had a shared sense of the importance of religious and ethnic identity. In such a social context, there was solid ground for appeals to common values and a shared moral outlook. Today, there is often much less common ground given the socio-cultural and religious diversity of our contemporary, globalized communities. At a deeper level and as illustrated in part by Gerald's moral outlook, people are also more likely today to recognize that an emphasis on common human experience can keep us from recognizing the distinctive and unique moral insights found in specific moral outlooks.

Building on a contemporary, postmodern awareness of the situatedness of all human knowing and doing, some people today strive to establish a foundation for moral praxis by building on the strengths of specific moral perspective, especially faith perspectives. For instance, in the second story told above Nikki seeks to find a secure foundation for her faith and moral outlook in the wisdom and official teachings of Catholicism. However, when we think that our own distinctive moral perspective gives us such a superior perspective that we do not need to take other moral outlooks into account, there is likely be little openness to appreciating the genuine moral insights in alternative perspectives.

Among others today an awareness of difficulties in formulating a coherent moral outlook and establishing a framework for public moral discourse has sparked a greater level of critical moral reflection. In some cases, however, critical reflection has degenerated into skepticism and even destructive doubt. More fully, we live in an age of doubt. The institutions that once stood as symbols of stability and social and moral values are often questioned today. Business corporations, political parties, and even churches no longer command the respect they once did. For some people our contemporary tendency to doubt moves beyond constructive critical reflection and becomes an acid that corrodes the fabric of life and creates a breeding ground for uncertainty, suspicion, lack of confidence and even cynicism, skepticism and despair. In an age in which there is an increasing awareness of how all human knowing and doing is situated within and bound by specific life contexts, focusing only on a sense of common humanity and how the moral wisdom of specific religious communities and traditions can limit our moral vision is likely to encourage destructive doubt.

Overall, an awareness of the difficulties that can arise in creating space for people of diverse perspectives to share their moral outlooks and discuss moral issues may tempt us to question whether or not it is any longer possible to forge spaces for the public discussion of moral issues. However, as will be discussed in the next two sections, we can begin to move beyond these difficulties if we examine carefully the dynamics of moral experience with a focus 
on moral awareness, and then consider how people can learn to draw insight from their religious convictions in contributing to public discussions of socio-moral issues.

Morality and the Dynamics of Moral Awareness

As human beings we are moral beings; we see the world not just as it is but as we judge it ought to be. For instance, in seeing a child being pushed roughly to the ground by another child on a playground, we are likely to see more than the physical actions taking place. We are likely to see violence, or abuse, or bullying; and we are likely to judge that it should not be taking place. However, even though we are by nature moral beings, our experience and expression of moral concerns are not on the level of moral experience as common human experience. Rather, we become aware of and then think and talk about the moral dimensions of life at the level of moral experience as uniquely and distinctively human experiences. That is, who we are as unique persons situated in specific life contexts shapes and to some extent determines how we experience and express the tug of morality, how we are drawn to attend to and articulate concerns about the well being of persons and communities in particular situations.

To gain a better understanding of the dynamics of moral experience we can examine three dimensions of moral awareness. First, moral awareness can be experienced as moral perception in tandem with primary moral reactivity. Imagine for instance, seeing a store clerk intentionally cheating a customer by giving him the wrong change. Similarly, imagine seeing a person pick up and turn in a lost wallet to a store clerk. When we see morally troubling or morally praiseworthy behavior we may be led to stop, take notice, and become aware of the moral dimensions of a situation through strong feelings or preverbal impulses. Such primary moral reactivity can often be expressed by talking about what is just or fair, on the one hand, or morally exemplary, on the other. However, the more intense our gut reactions are, the less adequate any conceptual representation of these reactions is likely to seem. Thus, negative moral gut reactions can often be most fully described as inner impulses making us aware of a moral lack or incompleteness, while positive moral gut reactions may be said to lead to a sense of moral fittingness. ${ }^{6}$ From a Christian perspective, the language of natural law provides one way of discussing moral perception and primary moral reactivity. As noted in the Catechism of the Catholic Church (CCC), "The natural law expresses the original moral sense which enables man [and woman] to discern by reason the good and the evil, the truth and the lie" (CCC, No. 1954). (See also the apostle Paul's understanding of the natural law in Romans 2.)

Second, people's gut reactions to morally charged situations may be preceded, accompanied, or followed by affective arousal and response. When experienced as affect or emotion, moral awareness is moral sensitivity. In commenting on the distinctive nature of moral sensitivity Daniel McGuire notes that "affections keep us close to the flesh and find the reality beneath abstractions and statistics." Additionally, there are two poles to affective moral sensitivity. First, it is experienced as an inner impulse of the heart. Second, this inner impulse leads outward toward a greater sense of connectedness with life, and especially with other human beings. Hence, affective moral sensitivity can be expressed through concepts such as caring and

\footnotetext{
${ }^{6}$ For classic studies of moral perception and how it is analogous to aesthetic perception see Maurice Mandelbaum, The Phenomenology of Moral Experience (Glenco: Free Press, 1955), and Wolfgang Kohler, The Place of Values in a World of Fact (New York, Liveright Publishing, 1938). See also Elaine Scarry, On Beauty and Being Just (Princeton: Princeton University Press, 1999).

${ }^{7}$ Daniel McGuire, The Moral Choice (New York: Doubleday, 1978), 295.
} 
connectedness. ${ }^{8}$ In discussing affective moral sensitivity from a Christian perspective the CCC points out that "feelings or passions are emotions or movements of the sensitive appetite that" lead us to be attentive to the needs and concerns of others and incline us "to act or not act in regard to something felt or imagined to be good or evil" (CCC, No. 1763). Christian moral sensitivity can also be discussed as love and be explored scripturally through reflection on such texts as Psalm 136, Matthew 22:34-60, and Mark 12-28-34.

Third, people's primary reactions and affective sensitivity to morally charged situations may be extended by cognition. For instance, a sense of justice that is rooted in primary gut reactions may be refined by an affective connection to others and extended through thought so that people distinguish between distributive and commutative justice. In such cases, understandings of distributive justice express norms concerning the disbursement of the goods of the earth based on the claim that all people should have some share in these goods. Standards of commutative or basic community justice express norms about the importance of honoring social exchanges between people (such as contracts, sales agreements, or agreed upon terms and conditions of employment between a worker and his employer). ${ }^{9}$ Overall, the cognitive processing of morally charged situations is often expressed in terms of personal and social norms that can serve as guides for making sense of the moral dimensions of life experiences. Personal norms are internalized conceptions of obligation. Social norms consist of expectations, obligations, and sanctions anchored in social groups. When we are in the midst of morally charged situations our awareness may be filtered, often unconsciously, by internalized norms. For instance, as a person watches another person discreetly drop an item into a bag in the middle of a store, she may be seeing someone violating the norm against shoplifting. From a faith perspective, the moral norms of a religious community give expression to its collective moral wisdom. As such, they can serve as guides for making sense of morally charged situations in the light of faith. ${ }^{10}$

Ideally, in a mature moral outlook, the three dimensions of moral awareness would be fully developed and integrated with one another. This is, however, rarely the case. Drawing insight from Christian theology and contemporary psychology, it can be noted that moral

\footnotetext{
${ }^{8}$ Affective moral awareness or moral sensitivity is based on the human capacity for empathy. See Martin Hoffman, "Is Altruism Part of Human Nature?" Journal of Personality and Social Psychology 40 (1981):121-137; and Martin Hoffman, "Empathy: Its Development and Prosocial Implications," in Nebraska Symposium on Motivation vol. 25, ed. C.B. Keasey (Lincoln, NE: University of Nebraska Press, 1978). See also John C. Gibbs, Moral Development \& Reality (Thousand Oaks: Sage, 2003), 78-11; Larry P. Nucci, Education in the Moral Domain (Cambridge: Cambridge University Press, 2001), 107-123; and Robert C Solomon, True to Our Feelings: What our Emotions are Really Telling Us (Oxford; Oxford University Press, 2007). For classic discussions of how affect can serve as the basis for a moral outlook focused on care for others see Carol Gilligan, In a Different Voice (Cambridge, MA: Harvard University Press, 1992); Nel Noddings, Caring: A Feminine Approach to Ethics and Moral Education, $2^{\text {nd }}$ ed. (Berkeley: University of California Press, 2003); and Nel Noddings, Educating Moral People (New York: Teachers College Press, 2002).

${ }^{9}$ For a fuller account of the types of justice see David Hollenbach, Justice, Peace, \& Human Rights (New York: Crossroad, 1988), 26-30.

${ }^{10}$ On norms and the formation of norms see Shalom H. Schwartz, "Normative Influences on Altruism," in Advances in Experimental Social Psychology vol. 10, ed. L. Berkowitz (New York: Academic Press, 1977); J. Philippe Ruston, Altruism, Socialization, and Society (Englewood Cliffs: NJ: Prentice-Hall, 1980), 41-51, 75-76, and 96-103; and Nucci, Education in the Moral Domain, 3-75.
} 
awareness can be distorted by sin and evil. ${ }^{11}$ There are also many personal and social influences that lead to the selective development of moral awareness. For instance, research has shown that both men and women are capable of understanding and utilizing a justice-oriented moral outlook (grounded in primary moral reactivity and norms of fairness) and a care-oriented moral outlook (grounded in affective moral sensitivity). Yet, because of the way human beings have evolved as social beings and the influence of current social influences, there is a tendency for men to prefer an ethic of justice while women often prefer an ethic of care. ${ }^{12}$ It is also important to note that even among people with mature moral outlooks, there can be differences in moral awareness because of the distinctive ways their lives have unfolded and influenced their moral development. ${ }^{13}$ Additionally, religious beliefs and practices shape moral awareness in distinctive ways. For instance, a religious tradition or even a specific religious community may emphasize one aspect of moral awareness more than others, or shape in distinctive ways how an aspect of moral awareness is developed - consider, for instance, the similarities and differences in the ways affective moral awareness is shaped into Buddhist senses of compassion and Christian senses of love. ${ }^{14}$

Overall, because we as human beings are moral beings, we can expect other people to be attentive to moral concerns and to bring some sense of moral perception, moral sensitivity, and attunement to moral norms into their interactions with others. At the same time, we can expect people to express their moral awareness in many differing ways depending on how their moral outlooks have developed within the distinctive contexts of their personal and social lives. As will be discussed in the next section, building upon an understanding of the multi-faceted nature of morality and moral awareness, it is possible to offer a few basic guidelines for how people can learn to draw insight from their religious convictions in contributing to public discussions of socio-moral issues.

Learning to See Religiously and Public Moral Discourse

First, in guiding people to learn to see the world religiously, religious educators should help people to recognize and resist all forms of false humanism. Such false understandings of the human person minimize the unique contributions that people of faith can make to public discussions of socio-moral issues as they draw insight from their distinctive faith perspectives.

The Urban Plunge leaders and Campus Ministry staff members in the stories told earlier strive to create public discussion forums in which all aspects of human life, including morality and spirituality, can be discussed in terms of common, sharable human experience and in which all references to situated and distinctive life experiences are excluded. They have adopted what are, in essence, false understandings of human experience. As pointed out above, people do not

\footnotetext{
${ }^{11}$ See James F. Keenan, Moral Wisdom $2^{\text {nd }}$ ed. (New York: Sheed and Ward, 2010), 45-65; Richard M. Gula, Reason Informed by Faith: Foundations for Catholic Morality (New York: Paulist, 1989), 89-122; and Ervin Staub, The Psychology of Good and Evil (Cambridge: Cambridge University Press, 2003).

${ }^{12}$ See the discussions of empirical studies of an ethic of care in Mary M. Brabeck ed. Who Cares?: Theory, Research, and Educational Implication of the Ethic of Care (New York: Praeger: 1989), especially Muriel J. Bebeau and Mary Brabeck, "Ethical Sensitivity and Moral Reasoning among Men and Women in the Professions," 144-163.

${ }^{13}$ For a study of the similarities among yet distinctive nature of mature moral outlooks see Anne Colby and William Damon, Some Do Care: Contemporary Lives of Moral Commitment (New York: Free Press, 1992).

${ }^{14}$ Compare for instance the understanding of Buddhist compassion in "Compassion as a Liberating Power" with the understanding of Christian love explored in Virtuous Passions - John Makransky, Awakening Through Love: Understanding Your Deepest Goodness (Boston: Wisdom Publications, 2007), 157-200; and Simon G. Harak, Virtuous Passions: The Formation of Christian Character (New York; Paulist Press, 1993).
} 
experience life at the level of common human experience. We experience life as specific persons who live within specific social contexts and who have often unique and distinctive moral outlooks.

In order for public moral discussions to be fruitful both common, underlying social concerns and differences in moral outlooks must be acknowledged. Underlying common concerns provide, at a minimum, a reason for gathering for public discussion. At the same time, recognizing differences can enable those involved to name disputed issues clearly. At a deeper level, as Parker Palmer notes, "our differences are among our greatest assets." 15 Sharing differences in moral outlooks can expand our moral awareness. When recognition and discussion of differences is not allowed in public forums, moral discourse is impoverished rather than being enriched. And, in contributing to public conversation about social issues, insights grounded in differing faith convictions may confirm and strengthen one another at times, while at other times they may lead people from differing religious traditions to make unique and even challenging and corrective contributions to public discussions.

Forms of false humanism are often embodied today in institutional ideologies and practices based on secularism. Hence, there is a need for a second guideline. Specifically, in guiding people to learn to see the world religiously, religious educators should lead people to recognize the inadequacies of and to resist all forms of secularism.

Secularism can be distinguished from secularization. During the modern era there was a secularization of society, that is, a separation of many areas of social life from religion, and the creation of public spaces for discourse that were independent from the influence of religious (and most often Christian) institutions. This process of secularization, as Michael J. Himes and Kenneth R. Himes, point out, "has been largely beneficial."16 It enabled scientific enquiry, the arts, economic institutions, and other aspects of human activity to develop within their own social spheres, free from the often stifling influence of religious authorities who did not fully understand the inner logic and operating dynamics of these spheres. Moreover, because of the secularization of society public spaces were created for discussing social issues in which people stepped back from their specific life perspectives, including their faith commitments, in order to ensure that civil discourse was not plagued by destructive conflicts. However, when the process of secularization is taken to the extreme, it fosters secularism. Secularism is the ideological conviction that religion and belief in the spiritual and transcendent dimensions of life have no place in public life. From the perspective of secularism, faith convictions should be seen as purely private matters. Secularism is problematic because it obscures from view the social dimensions of faith convictions and how insights drawn from personal experience and religious traditions provide the foundations for our distinctive moral outlooks. For instance, in the stories told earlier, because they adopted a secularist outlook the representatives of the institution of higher learning that Gerald attended and at which Nikki worked, were unable to articulate how the Jesuit, Catholic identity of their school provides a foundation for university programs. They were also unable to recognize how they could create forums for public moral discourse in which they and others could share insights from their uniquely insightful moral outlooks as they address socio-moral issues of common concern.

\footnotetext{
${ }^{15}$ Parker J. Palmer, Healing the Heart of Democracy: The Courage to Create a Politics Worthy of the Human Spirit (San Francisco: Josey Bass, 2011), 2.

${ }^{16}$ Michael J. Himes and Kenneth R. Himes, Fullness of Faith: The Public Significance of Theology (New York: Paulist, 1993), 3. They discuss the differences between secularism and secularization on 2-3.
} 
Third, as people who ground their lives in their faith commitments have reacted against the false humanism and secularism of our age, they have sometimes given into the temptation to overstate the extent to which we can draw insight from our religious traditions. Hence, in order for contemporary forums for public moral discourse to be fruitful a third guideline is needed. Specifically, in guiding people to see the world religiously, religious educators should encourage people to resist all forms of religious imperialism, that is, claims that the moral outlook of one religious tradition is superior to other outlooks coupled with attempts to force this moral outlook on others. Even when people of faith engage in civil protest and disobedience, our stance should be a dialogical one, aimed at sparking or contributing to public discussion of important social issues. From a Christian perspective, we should approach life with humility, always remembering that God has and continues to make God's self known within other religions and that the Christian church is not the Kingdom or Reign of God. Moreover, as Christians, we are called to follow the nonviolent way of Jesus and to be willing to face personal and communal risks in our encounters with others as we strive to move the world closer to the realization of what is authentically good and true.

Once our moral vision is clarified by the above guidelines, a fourth one can be offered. In guiding people to learn to see the world religiously, religious educators should help people to recognize how religious education should always go beyond learning how to be religious within a specific religious community and explore how believers are called to bring their faith to bear in all aspects of their lives.

Christian religious education should, of course, teach Christians about their faith tradition while also forming them to some extent, depending on the learning context, to be practicing members of a Christian faith community. In helping Christians grow in faith, Christian religious educators should also explore how Christians are called to carry forward the mission of the church to welcome and work to bring about the fuller realization of God Reign, God's Peace and Justice, within the world. Additionally, Christians are called to respect people of other religions and to be open to the ways their faith commitments reflect the light of truth and can shed light on the pressing issues of the world. ${ }^{17}$ Overall, Christian religious education should educate people for life within as well as life beyond Christian communities. It should have both internal, communal and outward looking, public and social dimensions. In should form Christians for membership in their religious communities and to carry their faith into all aspects of their everyday lives in the world. Regarding the latter, building upon an awareness that we as human beings are moral beings who are created in God's image, Christians can confidently hope to enter into public conversations about socio-moral issues with people of other faiths and all people of good will. Based on an understanding of the various ways that moral awareness can be shaped

${ }^{17}$ See Vatican II, "Declaration on the Relationship of the Church to Non-Christian Religions," especially, no. 3, which states: "The Catholic Church rejects nothing which is true and holy in [other] religions. She looks with sincere respect upon those ways of conduct and of life, those rules and teaching which, though differing in many particulars from what she holds and sets forth, nevertheless of reflect a ray of that Truth which enlightens all" people (http://www.vatican.va/archive/hist councils/ii_vatican council/documents/vat-ii decl 19651028 nostraaetate en.html). See also the Declaration on the Unicity and Salvific Universality of Jesus Christ and the Church, no. 2, which states that "inter-religious dialogue, which is part of the Church's evangelizing mission, requires an attitude of understanding and a relationship of mutual knowledge and reciprocal enrichment, in obedience to the truth and with respect for freedom"

(http://www.vatican.va/roman_curia/congregations/cfaith/documents/rc_con_cfaith_doc_20000806_dominusiesus_en.html). 
and then experienced, Christians should strive to bring their distinctive moral outlooks into public conversations as they seek to contribute to discussions about the common good while at the same time being open to learning from others.

\section{Bibliography}

Brady, Judith Ann. A Place at the Table: Justice for the Poor in a Land of Plenty. New London: CT: Twenty-Third, 2008.

Blumberg, Sherry H. "Repairing the World: The Place of Mitzvot in Children's Spiritual Lives," in Nurturing Child and Adolescent Spirituality: Perspective from the World's Religious Traditions, edited by Karen Marie Yust, Aosrte N. Johnson, Sandy Eisenberg Sasso, Eugene R. Roehlkepartain, and Vishal Agarwal. Lanham, MD: Rowan and Littlefield, 2006.

Brabeck, Mary M., ed. Who Cares?: Theory, Research, and Educational Implication of the Ethic of Care. New York: Praeger: 1989.

Cahill, Lisa Sowle. Love Your Enemies: Discipleship, Pacifism, and Just War Theory. Minneapolis: Fortress, 1994.

Cho, Francisca. "Ritual Action in Confucianism" in "Ritual." In The Blackwell Companion to Religious Ethics, edited by William Schweiker. Malden, MA: Blackwell, 2005.

Christie, Dolores L. Moral Choice: A Christian View of Ethics. Minneapolis: Fortress, 2013.

Colby, Anne and William Damon. Some Do Care: Contemporary Lives of Moral Commitment. New York: Free Press, 1992.

Congregation for the Doctrine of the Faith, Declaration on the Unicity and Salvific Universality of Jesus Christ and the Church.

http://www.vatican.va/roman_curia/congregations/cfaith/documents/rc_con_cfaith_doc_2 0000806 dominus-iesus en.html

Confucius, Confucius Analects. Translated by Slingerland, Edward. Indianapolis, IN: Hacket, 2003.

Dorff, Elliot N. The Way into Tikkun Olam (Repairing the World). Woodstock, VT: Jewish Lights Publishing, 2005.

Dorff, Elliot N. and Newman, Louis E. eds. Contemporary Jewish Ethics and Morality. New York: Oxford, 1995.

Elias, John. Moral Education: Secular and Religious. Malabar: FL: Robert E. Krieger, 1999.

Gibbs, John C. Moral Development \& Reality. Thousand Oaks: Sage, 2003.

Gilligan, Carol. In a Different Voice. Cambridge, MA: Harvard University Press, 1982.

Groome, Thomas H. Christian Religious Education. San Francisco: Josey-Bass, 1980.

Gula, Richard M. Reason Informed by Faith: Foundations for Catholic Morality. New York: Paulist Press, 1989.

Gutierrez, Gustavo. The Power of the Poor in History. Maryknoll; Orbis, 1983.

Himes, Michael J., and Kenneth R. Himes. Fullness of Faith: The Public Significance of Theology. New York: Paulist Press, 1993.

Hoffman, Martin. "Is Altruism Part of Human Nature?” Journal of Personality and Social Psychology 40 (1981):121-137.

. "Empathy: Its Development and Prosocial Implications." In Nebraska Symposium on Motivation vol. 25, ed. C.B. Keasey. Lincoln, NE: University of Nebraska Press, 1978.

Harak, Simon G. Virtuous Passions: The Formation of Christian Character. New York; Paulist 
Press, 1993.

Hollenbach, David. Justice, Peace, \& Human Rights. New York: Crossroad, 1988.

Keenan, James F. Moral Wisdom, $2^{\text {nd }}$ ed. New York: Sheed and Ward, 2010.

Kohler, Wolfgang. The Place of Values in a World of Fact. New York, Liveright Publishing, 1938.

Kupperman, Joel J. "Ren and Li in the Analects," in Confucius on the Analects, edited by Van Norder, Bryan W. Oxford: Oxford University Press, 2002.

Mandelbaum, Maurice. The Phenomenology of Moral Experience. Glenco: Free Press, 1955.

Makransky, John. Awakening Through Love: Understanding Your Deepest Goodness. Boston: Wisdom Publications, 2007.

McGuire, Daniel. The Moral Choice. New York: Doubleday, 1978.

Narvaez, Darcia and James Rest. "The Four Components of Acting Morally." In Moral Development: An Introduction, 385-400. Allyn and Bacon, 1995.

Noddings, Nel. Caring: A Feminine Approach to Ethics and Moral Education $2^{\text {nd }}$ ed. Berkeley: University of California Press, 2003. . Educating moral people. New York: Teachers College Press, 2002.

Nucci, Larry P. Education in the Moral Domain. Cambridge: Cambridge University Press, 2001.

Ogletree, Thomas W. Hospitality to the Stranger: Dimensions of Moral Understanding. Philadelphia: Fortress, 1985.

O'Hare, Padraic. "The Renewal of Education and the Nurturing of Justice and Peace." In Education for Peace and Justice, edited by O'Hare, Padraic. San Francisco: Harper and Row, 1983.

Palmer, Parker J. Healing the Heart of Democracy: The Courage to Create a Politics Worthy of the Human Spirit. San Francisco: Josey Bass, 2011.

Perrin, Norman. Jesus and the Language of the Kingdom: Symbol and Metaphor in New Testament Interpretation. Philadelphia: Fortress, 1976.

Pineda, Ana Maria. "Hospitality," in Practicing our Faith, edited by Dorothy C. Bass.San Francisco: Josey Bass, 1997.

Rest, James R. with Robert Barnett, Muriel Bebeau, Deborah Deamer, Irene Getz, Yong Lin Moon, James Spickelmer, Stephen J. Thomas, and Joseph Volker. Moral Development: Advances in Research and Theory. New York: Praeger, 1986.

Rest, James R. "Morality." In Manual of Child Psychology vol. 3, volume edited by J. Flavell and E. Markman, general editor P. Mussen, 556-629. New York: Wiley, 1983.

Ruston, J. Philippe. Altruism, Socialization, and Society. Englewood Cliffs: NJ: Prentice-Hall, 1980.

Scarry, Elaine. On Beauty and Being Just. Princeton: Princeton University Press, 1999.

Schwartz, Shalom H. "Normative Influences on Altruism." In Advances in Experimental Social Psychology vol. 10, edited by L. Berkowitz. New York: Academic Press, 1977.

Solomon, Robert C. True to Our Feelings: What our Emotions are Really Telling Us. Oxford; Oxford University Press, 2007.

Staub, Ervin. The Psychology of Good and Evil. Cambridge: Cambridge University Press, 2003. Vatican II, Declaration on the Relationship of the Church to Non-Christian Religions. http://www.vatican.va/archive/hist_councils/ii_vatican_council/documents/vat-ii_decl_19651028_nostraaetate en.html 